\title{
The Expansion of Capital and Uneven Development on a World Scale
}

\author{
By
}

John Weeks

1999

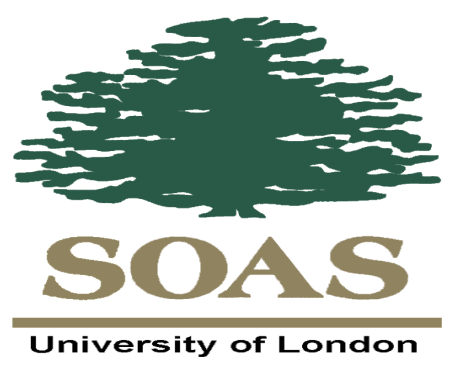

Centre for Development Policy \& Research (CDPR)

School of Oriental and African Studies, University of London

Thornhaugh Street, Russell Square, London WC1H 0XG, United Kingdom

Telephone: +44 (0)20 7898 4496,

Fax: + 44 (0)20 7898 4519,

E-mail: CDPR@soas.ac.uk

URL: http://www.soas.ac.uk/centres/cdpr 
Introduction $^{*}$

That the development of capitalism is uneven is a fundamental conclusion of the Marxian analysis of accumulation, which distinguishes it from the equilibrium approach of the neoclassicals. In the neoclassical approach, competition and the movement of capital are equilibrating forces which narrow differences among firms, regions, and countries. Indeed, an apparent anomaly in neoclassical analysis is its prediction of a convergence of development among these, and persistent inequality among agents, with the latter arising because the 'initial' distribution of productive assets is taken as given. Recent work, especially by UNCTAD (1997) and Pritchett (1997), has demonstrated that over the last one hundred years there is no evidence of a levelling convergence of growth rates, and, therefore, levels of per capita income).

This paper provides further evidence of the uneven development of capitalism on a world scale, and offers a theoretical explanation for the phenomenon. We explain divergence in terms of primary and secondary uneven development. Primary uneven development arises because of the more dynamic expansion of capitalist countries relatively to countries in which capitalism is incipient. This difference is inherent in the social relations of capital. Secondary uneven development occurs within the group of predominantly capitalist countries, due to competition and adoption of technical innovations within the social relations of capital. The former generates divergence; the latter exhibits a cyclical pattern of convergence and divergence, with convergence the long term tendency.

The issue of divergence is introduced by an elaboration of the orthodox or neoclassical argument that trade, and trade combined with capital mobility, should result in the convergence of levels of development world-wide. As for so much of orthodox theory, this analysis is instructive by demonstrating the highly restrictive conditions under which its conclusions follow logically. The discussion then turns to the Marxian framework. At a superficial level, Marxian theory could also be interpreted as producing convergence, that non-capitalist social relations are swept away in favour of capitalist relations. However, this interpretation reads Marx's contribution from a neoclassical perspective. After developing an analysis of divergence or uneven development, empirical evidence is presented, in order to inspect the particular form divergence has taken over the last four decades.

\section{Convergence in Neoclassical and Marxian Theory}

The task of a theory of growth and development has been succinctly summarised by Pritchett:

Any theory that seeks to unify the world's experience with economic growth and development must address at least four distinct questions: [1] What accounts for continued per capita growth and technological progress of [the developed capitalist countries]...? [2] What accounts for the few countries that are able to initiate and sustain periods of rapid growth in which they gain significantly on the leaders? [3] What accounts for why some countries fade and lose the momentum of rapid growth? [4] What accounts for why some

\footnotetext{
* The author is Professor of Development Economics at the School of Oriental \& African Studies. Thanks go to Anwar Shaikh, Costas Lapavitsas and Ben Fine for comments.
} 
countries remain in low growth for very long periods? (Pritchett 1997, p. 15, numbers added)

While a theory of capitalist development must address Pritchett's four questions, he poses them without a specification of the nature of capitalist accumulation. Analytically prior to his four questions is, why does uneven development characterise the world? This implies a second, historical, question: how does one account for the relative concentration of capitalist development in Western Europe and the settler colonies of Western Europe? ${ }^{\mathbb{L}}$

According to neoclassical economic theory, the distribution of levels of development on a world scale should be a simple phenomenon, derivative from internal characteristics of each country, and trade and capital flows. Since economic phenomena are governed by universal laws of the behaviour of individual agents, there is no theoretical basis to expect some countries to develop faster than others. External factors, also universal in character, would tend to eliminate all but minor differences in levels of development. Consider first the convergence process implied by the neoclassical static trade model. Exchange between countries, even in the absence of any movement of capital or labour between countries, should result in a tendency for wage rates and profit rates to equalise (so-called factor price equalisation). Thus conclusion is based upon a number of specific assumptions: 1) all countries have access to the same technology of production (implying that every country can potentially produce the same range of commodities); 2 ) output results from capital and labour, which can be substituted for each other in the production process, ${ }^{4}$ ) the domestic structure of demand in each country is the same; 4) if one measures the 'factor-intensity' of a product by the ratio of capital to labour, and ranks all products by this ratio, the ordering is not affected by changes in wage rates or profit rates, and 5) markets internal to each country are perfectly competitive.

Under these assumptions, let a country shift from a closed economy ('autarky') to so-called free trade. Each country will export the commodities that use intensively the factor of production that is abundant, and import commodities that are intensive in the factor which is scarce in the country. As a result of the shift in resource use, the demand for the abundant factor will rise (increasing its price), and the demand for the scarce factor will fall (decreasing its price). When all adjustments are complete, wage rates and profit rates will be the same in all free-trading countries.

Even in its own terms, the conclusion is absurd. It implies, for example, that average wages should have fallen more-or-less continuously in the advanced capitalist

\footnotetext{
${ }^{1}$ The only developed country not in these two categories is Japan. Singapore qualifies on per capita income, but for analytical purposes should be viewed not as a country but a city-state (e.g., it has no agricultural sector).

${ }^{2}$ See Jones (1997), where he argues that all countries would tend to have similar rates of investment.

${ }^{3}$ In a neoclassical world, every product is generated from a 'production function' that allows for substitution among inputs.

${ }^{4}$ The theory can be generalised to include labour of different skills and capital equipment of different types, as long as these are all available to all countries. The factor price equalisation conclusion does not follow if there are production inputs that are specific to countries.

${ }^{5}$ This eliminates so-called 're-switching', in which case changes in the ratio of profits to wages can result in what was previously a 'labour-intensive' technique becoming relatively 'capital-intensive' (see Weeks 1989, chap. 10).
} 
countries over the last one hundred years (including the wages of the skilled), not merely to have risen slower than in the underdeveloped countries. ${ }^{6}$ However, the absurdity of the theory is instructive. In a world in which all countries apply the same technology there would be no basis for major differences in levels of development. The concrete equivalent of the abstract assumption of perfect competition is that product and input markets operate effectively to allocate resources. For this to occur, it would be necessary for production to be organised within capitalist social relations. If all countries were fully capitalist, utilising the same technology, then, indeed, 'factor prices' would tend to equalise, though the process would be uneven. Therefore, neoclassical trade theory reaches an absurd theoretical conclusion, which is refuted by empirical evidence, because it excludes from its analysis the causes of uneven development.

If one extends the neoclassical analysis to allow for capital flows, then the static convergence conclusion becomes dynamic: the combination of specialisation according to comparative advantage and the movement of capital from labour scarce (developed) to labour abundant (underdeveloped) countries should combine for a powerful levelling effect. In neoclassical analysis the convergence conclusion is unassailable theoretically, and refuted empirically. There is no apparent exit from this contradiction within the neoclassical paradigm. The standard, off-the-shelf neoclassical explanation for disappointing growth rates is 'bad policies' by governments (the Policy Hypothesis). This is hardly a credible argument when low growth has persisted for at least one hundred years for many countries (Pritchett 1997). Even were this persistence not the case, state policy as an explanation for different growth rates in the long run offers no explanation for our second (historical) question: how the presently developed countries initially achieved their status (i.e., why policy wisdom was so geographically concentrated for one hundred years).

While not neoclassical, Gerschenkron's analysis of the 'advantages of the latecomer' (Gerschenkron 1962) has been employed in the mainstream literature to make sanguine predictions that differences in level of development will tend to narrow over time. The essence of his argument was that 'backward' countries have the advantage of drawing on a stock of technology that was developed by the advanced countries. Therefore, producers in backward countries can pass over less efficient technologies and move to the most developed ones. This, combined with appropriate institutional arrangements, ${ }^{2}$ can produce growth rates for 'late-comers' considerably higher than those of advanced countries during their underdeveloped period. There is clearly some insight in this analysis, but if taken as a general prediction, it collapses empirically.

\footnotetext{
${ }^{6}$ Wages in developed countries, as well as not declining in the long run, have risen relatively to wages in most underdeveloped countries.

${ }^{7}$ One would expect that neoclassically rational policy makers would, after a few decades, learn the 'correct' policies for growth.

${ }^{8}$ A contemporary example of the application of the Gerschenkron thesis is found in Jones (1997). 'Output per worker grows in the long run because of the creation of ideas', 'Ideas diffuse across countries...eventually', and, thus, 'All countries eventually grow at the average rate of growth of world knowledge' (Jones 1997, p. 25). It would be difficult to find a better example of a syllogism. Among other things, this spurious logic ignores the possibility that the diffusion of 'ideas' (undefined) has a cost, and that 'knowledge' (also not defined) might be controlled by the 'creators' of that knowledge.

${ }^{9}$ Gerschenkron placed great emphasis upon actions by the state to facilitate capital accumulation. This aspect of his analysis is rarely stressed in the current literature. See Griffin (1989, pp. 100-101) for a discussion.
} 
Most underdeveloped countries have not closed the development gap with advanced countries; very few have done so. The analysis may establish the possibility of faster growth rates for 'late-comers', but does not explain why it occurs so infrequently.

On a mechanistic reading of Marx, his theory of capitalism can be interpreted as predicting convergence of levels of development. If the spread of capitalist social relations is inexorable, then it would be only a matter of time until capitalist transformation of the entire world occurs. If capital moves seeking the highest rate of profit, and if profits are higher in underdeveloped countries, due to lower wages, then there would be net capital flow from developed to underdeveloped countries. As in the neoclassical case this would, through time, result in a narrowing of levels of development. An argument quite close to this is found in the work of Warren (e.g., Warren 1973).

This interpretation of capitalist development implies that capitalism is everywhere an engine for development; and a country is underdeveloped because its social relations are incompletely capitalist. The Dependency Hypothesis is the bestknown attempt to escape from this politically unpalatable and empirically questionable conclusion. The Dependency Hypothesis maintains that the development of the advanced countries has been at the expense of the underdeveloped countries. Dependency writers proposed various mechanisms by which this would occur, all of which reduce to underdeveloped countries suffering 'surplus' extraction by developed countries. Like the Policy Hypothesis, the Dependency Hypothesis fails to address the historical question: how did one set of countries emerge as the extractors of surplus, and another as the losers of surplus (Weeks 1982, pp. 119-20)?

Even if the historical question were solved, the Dependency Hypothesis proves fatally flawed by its inability to produce a logically consistent and empirically verifiable mechanism for surplus extraction. The 'profit remittance' mechanism fails on both counts. It is a logical contradiction to argue, on the one hand, that capital flows to underdeveloped countries because of high rates of return, and, on the other, to maintain that profits are remitted rather than re-invested. Therefore, it should not surprise one that empirical evidence indicates that the magnitude of profit remittances between underdeveloped and developed countries is far below what would be necessary to have a substantial growth impact (Weeks 1985, chap 2), at least, before the debt crisis of the 1980s.

Dependency writers proposed 'unequal exchange' as an alternative mechanism for surplus extraction. The most common form of this is the 'declining terms of trade' argument, whose more mainstream manifestation is the Prebisch-Singer thesis. This is essentially an empirically-based argument: in international trade relative prices tend to move against underdeveloped countries due to the internal characteristics of developed and underdeveloped countries. $\frac{10}{10}$ While this may be the case for some primary

\footnotetext{
${ }^{10}$ In the Dependency interpretation, unequal exchange arises from the difference in power relations between 'centre' and 'periphery' countries. In the Singer-Prebisch argument, it is the nature of markets. In the peripheral countries, producers are competitive and productivity increases are passed on as price reductions in traded goods. In the centre countries, product markets are non-competitive, and productivity increases manifest themselves in part in higher price in trade. Thus, the world prices of exports from peripheral countries tend to stagnate or fall, while the prices of exports form centre countries tend to rise. The Singer-Prebisch argument was a product of the 1950s and 1960s, when economic rivalry among developed countries was latent, due to the dominant position of US capital.
} 
products, such as tropical beverages, empirical studies have not demonstrated that it systematically operates between the two sets of countries. An alternative somewhat immune to empirical refutation is the argument that differences in wage rates among countries result in systematic transfers of surplus (Amin 1976 and Emmanuel 1972). The logic is deceptively simple: if all countries use the same technology, then profit rates will be higher in countries with lower wages. The movement of capital to equate profit rates will lower prices in low-wage countries and raise them in high-wage countries. While international prices will appear as equal exchange, they mask a transfer of surplus.

This version of the unequal exchange argument is logically inconsistent (Dore and Weeks 1978). If the commodities in question are internationally traded, it is not possible for them to sell at different prices in different countries without ad hoc institutional assumptions. Profit rates cannot equalise, because prices must do so, except for non-traded commodities. 11 Even were there a tendency for profits to equalise, despite the contradiction of a common price in international trade, the analysis would imply a net movement of capital to underdeveloped countries to equalise profit rates. If this occurred, underdeveloped countries would grow faster than the developed, resulting in convergence, not the divergence that the hypothesis seeks to predict.

Finally, there is an underlying flaw in most versions of the Dependency Hypothesis: it does not attribute uneven development to capitalism. The initial division of the world between develop and underdeveloped countries is taken as given (the historical question is begged), and the surplus transfer mechanisms could apply to any historical period. 2 The task is to produce an analytical framework which accounts for divergence during the capitalist epoch, when differences in national and regional levels of development increased far beyond any that previously occurred.

\section{Competition and Uneven Development}

The explanation of divergence in levels of development has two parts: the character of capitalist accumulation and the nature of underdevelopment. In the Marxian literature these are 1) the process of accumulation, and 2) the articulation or interaction of modes of production. The historical emergence of capitalist social relations, wage labour within commodity production, produced the primary manifestation of uneven development, which is the division of the world into developed and underdeveloped countries. The interaction of technical change and competition within the developed capitalist countries generates a secondary uneven development, across industries and regions of the capitalist countries. To explain these assertions, one must consider the process of capitalist development and accumulation.

\footnotetext{
${ }^{11}$ For logical consistency, a given product must sell at a common price in international trade, regardless of its country of origin (ignoring transport costs). Then, profits cannot equalise across countries because wage rates differ and the technology of production is the same.

${ }^{12}$ This is not true of the Emmanuel-Amin version of unequal exchange. Their approach implicitly presumes the full development of capitalist social relations, or otherwise capital would not flow freely among countries.
} 
A capitalist society reproduces itself through the production and circulation of commodities. The general production of commodities that characterises capitalism derives from the exploitation of direct producers through wage labour. The development of wage labour resulted, and continues to result, from the separation of workers from their means of production. The most obvious form of this separation is the dispossession of agricultural producers from the land, but it also applies to artisanal production. Having been dispossessed, producers are reunited with the means of production via the agency of capital. They become, in effect, the instruments of capitalist production. This change in social relations is the basis for the dynamism of the capitalist mode of production. With labour 'free' from the means of production, capital in the form of money can marshal resources flexibly. Capitalist countries and the capitalist epoch are characterised by the movement of capital, as it shifts labour and other resources among industries and regions. While labour remains in possession of its means of production, capital is constrained in its movement. The division of the world during the late eighteenth and nineteenth centuries into advanced and backward countries, into colonial powers and colonies, arose from the dynamism of capitalist relations. This division represents the primary aspect of uneven development on a world scale: the United Kingdom, the United States, France, Germany, etc., on the one hand; and the myriad of colonies (e.g., India) and semi-colonies (Latin American countries), on the other.

In developing his analysis, Marx made methodological innovations that distinguished him from other critics of capitalism. Others, for example Proudhon and Sismondi, criticised capitalism for excesses caused by monopoly power. These allegedly produced an unequal exchange in which capitalists appropriated value from petty commodity producers and workers. In contrast, Marx argued that what appears as excesses of capitalism are the systematic outcomes of the process of competition. Competition, not the lack of it, is the source of instability, crises, and uneven development. This analysis for competition is the antithesis of the neoclassical approach, in which competition is the source of equilibrium and even development. Neoclassical theory treats competition in terms of the 'representative' firm, and competition creates a harmony in exchange. ${ }^{13}$ In general, radical critics of capitalism have accepted this approach. If one attributes the ills of capitalism to monopoly, one implicitly accepts that competitive capitalism would produce a more benign outcome. Much of dependency analysis implicitly or explicitly relies upon a concept of monopoly to explain underdevelopment (see Dore and Weeks 1978).

The nature of capitalist competition is revealed by beginning with the neoclassical analysis. In a neoclassical world, markets in the short run can be afflicted with 'firms' earning excess profits. The entry of new firms eliminates these so-called rents, by driving down prices, until profits have been equalised across all markets. The resultant prices are socially optimal, in that they reflect the social cost and benefit of each product. In this schema, competition not only generates market clearing and equilibrium; in the long term, it also produces a socially desirable outcome. NonMarxist critiques of this line of argument have tended to focus upon the absence of

\footnotetext{
${ }^{13}$ The orthodox theory of competition is treated in Weeks (1994).

14 Consider for example, the contradictory dependency view that profit rates are higher in underdeveloped countries, but profits are remitted to the developed ocuntries, thus reducing the investible surplus. This contradicition can be superficially resolved by assuming that foreign capital estalbishes monopoly positions in underdevleoped countries.
} 
competition in actual markets, due to various sources of market power. This 'market failure' approach accepts the fundamental orthodox argument: that competition is the mechanism that brings forth the benign aspects of capitalism. Neoclassical economists and most of their critics reach this conclusion, because competition is treated independently of its capitalist nature, and because production is ignored.

In a capitalist society, technical change creates the potential for variations in unit costs within sectors. At any moment in time, capitalist enterprises operate with machinery and plant whose total value (capital value) has not been recaptured through production and sales. If capitalists scrapped existing techniques and replaced them with more efficient ones when the latter first appear, most capitals would incur losses. The capitalists in an industry will, if possible, delay introducing new equipment, to achieve the optimal trade-off between current operating costs and losses on capital value. The problem need not be that lack knowledge of superior techniques, nor that capitals lack the finance to acquire them, though for some capitals, one or both may be true. The problem is more fundamental, involving a contradiction between the forces and relations of production. On the one hand, technical change offers more efficient methods of producing commodities. But, techniques are ruled by capitalist rationality, and their use or non-use is motivated by the drive for profit. Until the social relations of capital are satisfied, the law of private profitability delays innovations.

The delay in introducing innovations by some capitalists results in an uneven development of productive forces within an industry. At the level of appearances, competition fosters harmony and equilibrium, a tendency for a common price among producers of a similar product. Beneath this appearance uneven development rules, with enterprises earning different profit rates due to different production techniques. If there is a systemic crisis of capitalism, which takes the form of a drop in industry demand, higher cost producers will become non-viable. A systemic crisis can provoke a wave of bankruptcies across industries, and is the vehicle by which uneven development is reduced. In the absence of a systemic crisis of aggregate demand, an industry can be disrupted through invasion by a new producer, who comes armed with more advanced techniques and without obsolete capital whose value needs recovering. The entry of new capital into an industry involves not the process of equilibration, but is the vehicle to punish high cost producers for delaying technical change.

The movement of capital among industries has a contradictory effect: at the level of appearances it brings a tendency for profit rates to equalise; beneath this distributional form, it creates instability and crisis for resident enterprises. Therefore, it is the putatively benign aspects of capitalism, competition and innovation, which generate uneven development and crises (see Weeks 1981, chapters VII and VIII). This interaction between the forces of production (technical change) and the relations (competition) both undermines and rejuvenates the process of accumulation. This contradiction gives rise to the secondary aspect of uneven development, the decline and rise of industries and regions within societies that are dominated by capitalist relations. Certain industries, regions within countries, and even countries may decline, suffering from slow growth and unemployment. Such declines create the basis for their reversal, since they are associated with falling wage and non-wage costs. The ebb and flow of capital within predominantly capitalist societies creates at any moment relatively backward regions, but these change over time. 
This analysis predicts that primary uneven development, between capitalist and non-capitalist countries, will be enduring and difficult to overcome, while secondary uneven development will change with the movement of capital within and among the predominantly capitalist countries. It predicts a long-term tendency for convergence among predominantly capitalist countries, and a long term divergence between these countries and other countries, whose social relations are predominantly non-capitalist relations.

\section{Divergence Observed}

The concepts of primary and secondary uneven development provide the analytical basis for our review of the empirical evidence over the last four decades, 1961-1997. By chance major changes in the world economy occurred that roughly coincided with decades. In 1971, the United States government de-linked the dollar from gold, ending the post-war system of fixed exchange rates. Thus, the 1960s represented the last years of the post-war, Bretton Woods system of international economic management. To exchange rates instability were added two waves of oil price increases, in 1973-74 and 1978-79, which made the 1970s a decade of economic profound economic disorder. The debt crisis dominated the subsequent decade, during which average growth rates of almost all countries fell below their trend values. At the end of the decade, the Soviet Union collapsed, profoundly altering the international system. Thus, the period covers the last decade of what some have called the 'Golden Age' of twentieth century capitalism (Marglin and Schor 1988), its breakdown, and the subsequent international disorder.

From the perspective of the OECD countries, the 1960s were, indeed, a Golden Age, when growth rates across countries averaged more than five percent (see Table 1). This was also the period of fastest growth for the North African and Middle Eastern countries, and, at the least, 'silver' for the countries of the sub-Sahara and Latin America. For the Asian groups of countries, growth rates were higher subsequently, in the 1970s for the East and Southeast Asia group, and in the 1980s for South Asia. GDP growth rates are not the most accurate indicator of development, because of differences in population increase across country groups. Table 2 shows the ratio of per capita income for each group of underdeveloped countries to the OECD average. The ratio for the was lower in 1996-1997 than in 1961-1965 in every case but East and Southeast Asia group. For example, the average for the sub-Saharan countries fell from 3.4 percent to 1.5 percent, and Latin America from fifteen to eleven percent.

Primary and secondary uneven development are indicated in Figure 1, which presents the standard deviation of annual growth rates (in natural logarithms) across countries, within each regional grouping of the underdeveloped countries and the OECD countries. For the thirty-seven years, in only four is the variation among OECD countries equal to or greater than for any group of underdeveloped countries. Further, for no group of countries is there a trend. The variation across countries tends to be low among the developed capitalist countries, and high among the underdeveloped countries. Further, there is a strong cyclical element for the developed capitalist countries. Growth rates among these countries tended to diverge when the cross-country average growth rate were low, and to converge when average 
growth was high. 15 This implies that during periods of rapid accumulation, the levels of development among the capitalist countries tended to narrow. For none of the groups of underdeveloped countries is there a significant correlation between growth rates and their standard deviation. These statistics suggest that when the average rate of growth across all countries of the world was high, the developed capitalist countries tended to converge, while the underdeveloped countries did not, either among themselves, or relatively to the developed countries.

The extent to which underdeveloped countries have diverged from the developed capitalist countries over the last forty years is shown in Figures 2 and 3. These charts show the annual difference between the growth rates of each region and that of the OECD countries. Inspection of Figure 2 indicates that for the sub-Saharan countries, divergence has been the rule. For Latin America, only during a brief period, 1971-1976, did per capita income rise relatively to the OECD countries. For the North African and Middle Eastern countries, growth was above the OECD average in the 1960s, but continuously below in subsequent years. The South Asian countries (Figure 3) grew at a rate slightly above that for the OECD countries from the late 1970 s, allowing for a minuscule increase in relative per capita incomes, from 1.6 to 1.8 percent of the OECD level. At this rate of increase, it would take just over five hundred years for South Asian per capita income to converge to that of the OECD countries. The only strong convergence is for the East and Southeast Asian countries, which may well have been reversed for the foreseeable future by the regional financial crisis of the late 1990s.

Returning to Table 2, we can calculate the growth rates for country groups that would be necessary to return each group to its percentage level of the early $1960 \mathrm{~s}$. We assume that the OECD countries continue to grow at their long term rate of per capita income increase $\left(2.7\right.$ percent per annum). $\frac{16}{16}$ To return to their relative position after thirty-seven years (equal to the period, 1961-1997), the sub-Saharan countries would need to grow at over five percent per capita per annum. This is a full five percentage points above the average rate for these countries over the previous thirty-seven years. For Latin America, a four percent rate would be required, well above what the region average in any decade since 1960. More credible, but still unlikely, is the three percent rate for South Asia.

For what they are worth, World Bank estimates of regional growth rates for 1997-2006 confirm the probability that divergence will continue (bottom of Table 2). The World Bank projects that of the five underdeveloped regions, growth of per capita income in two will be below the OECD average (the sub-Sahara and North Africa and the Middle East). For Latin America and South Asia, the World Bank projects rates above the OECD countries', and well above historical performance. Only for the East and Southeast Asian countries is the projection consistent with the past. The 19971998 financial crisis of these countries casts doubt upon their ability to match past performance. Alternatively, we can take growth rates during 1994-1997 as indicating

\footnotetext{
${ }^{15}$ Over the twenty-seven years, 1961-1997, the correlation between the average rate of growth for seventeen countries and the standard deviation of the growth rate (across ocuntries by year) was .68 .

16 Pritchett points out that the growth of per capita income in the advanced countries has been remarkably stable. He shows, that if in 1961 one had estimated the per capita income of these countries for the early 1990s on the basis of previous long-term growth rates, the resulting estimate is within ten percent of the actual value (Pritchett 1997).
} 
the future trend, when every country group's per capita income growth was above its long term trend (with the exception of East and Southeast Asia). Were these high rates maintained to 2006, the relative position of all groups except the East and Southeast Asia would deteriorate.

Table 3 provides a crude measure of whether divergence can be explained by the degree to which a country group is linked to OECD growth. It suggests that lack of integration into the world economy cannot explain the long-term deterioration of relative per capita income for most underdeveloped countries. The table reports the simple correlation between annual growth rates of the OECD countries and each underdeveloped region. Of the five regions, the correlation is highest for the subSaharan countries. Growth for the sub-Saharan countries has tended to rise and fall with OECD growth, such that a one percent rise in the latter is associated with a .64 percent rise in the latter. However, over the long term OECD growth has been considerably higher. For all groups but the South Asian, there is significant correlation with OECD growth, but this has been associated with divergence, not convergence, in levels of development. We interpret this divergence to be the result of primary uneven development: the tendency for growth to be more rapid within predominantly capitalist social relations.

From a neoclassical perspective, part of the explanation for divergence can be explained by the absence of substantial redistribution of capital from advanced to underdeveloped countries. Table 4 shows net direct foreign investment by the major industrial economies, with the United States, United Kingdom, Germany, and Japan listed separately. In contradiction to the prediction of orthodox theory, the largest capitalist country, the United States, was a net recipient of foreign investment in all years. For all countries, there was a net flow to underdeveloped countries in the second half of the 1980s and 1990s, but relatively small. Even for the 1990s, foreign investment into the United States (seventeen billion UD dollars) approached the total for all underdeveloped countries (twenty-one billion). For the most part capitalist enterprises in advanced countries invest in their 'own' or other advanced countries.

Figure 4 shows the relative low level of foreign direct investment from advanced to underdeveloped countries. Except for China, foreign investment played a relatively small role in gross domestic investment. In Latin America, foreign investment was consistently below ten percent of total investment for the entire twenty-six year period, with no trend if one accounts for the cycle of depression and recovery; i.e., foreign investment accounted for about the same percentage in the mid1990 s as in the early 1970s. For the major Asian countries, foreign investment in no year reached as much as four percent of total investment. Contrary to what one might expect, foreign investment has been of greater relative importance in the sub-Saharan region than in Asia (the former greater than the latter in all but three years), 7 though considerably more volatile. The only major country in which foreign investment has played a substantially increasing role in total investment has been China. If China is excluded, the relative quantitative importance of foreign direct investment in underdeveloped countries was no greater in the 1990s than in the 1970s.

In this context, we can note that the evidence that most foreign direct investment is among developed capitalist countries, not from these countries to

\footnotetext{
${ }^{17}$ Most of the investment in the sub-Saharan region was in the mining sector, and had limited impact on affecting social relations in the countries.
} 
underdeveloped regions, is consistent with our concept of primary uneven development. One would expect that capital would flow to countries and regions characterised by capitalist social relations, for the persistence of non-capitalist relations is associated with institutional barriers to such flows.

Overall, the evidence is clear: during the three decades international capital did not dramatically accelerate its expansion into the underdeveloped world. On the contrary, the dramatic expansion was within the advanced capitalist countries. One would not expect capitalism to foster an equitable distribution of income and wealth on a national level. Nor did it foster a general convergence of capitalist development around the globe. Within capitalist relations, accumulation fosters convergence; while growth among countries at quite different levels of capitalist development produces divergence.

\section{Convergence and Divergence}

Our general conclusion, that capitalist countries converge among themselves, 18 and diverge from countries in which capitalist relations remain underdeveloped, does not explain the historical division of countries into the two groups. The historical explanation is straight-forward: the transition from slow to rapid economic growth is achieved through the development of capitalist social relations. This is essentially a process internal to each social formation, influenced, but not determined, by external factors. The extent to which trade and investment flows foster capitalist development within a social formation is primarily determined by the nature of the non-capitalist relations themselves. Since non-capitalist relations can take many forms, no general theory of transition to capitalism is possible.

Through a process taking several centuries, capitalism developed in Western Europe, ${ }^{20}$ establishing itself as the dominant mode of exploiting labour during the second half of the eighteenth century. During the nineteenth century, capitalism spread through the countries of this region. Because of the close integration of these countries in trade and finance, the development of capitalism in this region should be viewed as a single historical process; i.e., it should not be analysed as a number of separate transitions. The next 'wave' of capitalist development, in the late nineteenth and early twentieth centuries, involved only two transitions, Italy and Japan. In these countries, feudal and semi-feudal social relations were replaced by the social relations of capital. The other countries that emerged as capitalist during this period were settler states: the United States, Canada, Australia, New Zealand, and, unsuccessfully, Argentina and Uruguay. If the history of global capitalist teaches any lesson, it is that the transition is a protracted process, dominated by uneven development, in which divergence is the rule and convergence the exception.

\footnotetext{
${ }^{18}$ This is a central conclusion of the empirical work of Pritchett (1997).

${ }^{19}$ For example, see Byres (1997), for an analysis of the diversity in the development of capitalism in agriculture.

${ }^{20}$ That is, the United Kingdom, Ireland, France, Germany, the Low Countries, and Scandinavia.
} 
Table 1: GDP Growth Rates by Country Groups, 1961-1997

\begin{tabular}{|c|c|c|c|c|c|c|}
\hline Group: & $\underline{\mathrm{OECD}}$ & $\underline{\mathrm{SSA}}$ & $\underline{\mathrm{LA}}$ & ESEA & SoAsia & NAMF \\
\hline \multicolumn{7}{|l|}{ Period } \\
\hline$\overline{1961-1971}$ & 5.2 & 4.2 & 4.9 & 6.7 & 4.3 & 8.5 \\
\hline 1971-1980 & 3.5 & 3.8 & 4.2 & 7.2 & 3.4 & 6.8 \\
\hline 1981-1989 & 2.9 & 2.5 & 1.1 & 5.7 & 5.1 & 3.3 \\
\hline 1990-1997 & 2.4 & 2.0 & $\underline{3.9}$ & $\underline{5.6}$ & $\underline{4.5}$ & $\underline{3.5}$ \\
\hline average & 3.6 & $\overline{3.1}$ & 3.5 & $\overline{6.4}$ & $\overline{4.4}$ & $\overline{5.6}$ \\
\hline World Bank & & & & & & \\
\hline $\begin{array}{l}\text { Predictions, } \\
\text { 1997-2006 }\end{array}$ & 2.8 & 4.1 & 4.2 & $6.0^{*}$ & 5.9 & 3.6 \\
\hline
\end{tabular}

Notes: *The World Bank predicts a GDP growth rate for East and South East Asia of 7.6 percent per annum, and per capita as 6.6. This has been reduced to 6.0 for GDP and 4.5 for GDP per capita for two reasons: 1) the collapse of ESEA growth rates in 1997 and 1998 makes 7.6 an impossible target; and 2) the implied rate of population increase (one percent per annum) is certainly too low.

North Africa and Middle East group covers 1993-1997. China excluded from Asia groups.

OECD (Organisation of Economic Cooperation and Development, developed countries) - Australia, Austria, Belgium, Canada, Denmark, Finland, France, Germany, Ireland, Italy, Japan, Netherlands, New Zealand, Norway, Portugal, Spain, Sweden, Switzerland, United Kingdom, United States of America.

SSA (Africa south of the Sahara) - All continental countries south of the Sahara except Eritrea, Djibouti, Namibia, South Africa, Somalia

LA (Latin America) - All Spanish-speaking countries (except Cuba) and Brazil.

ESE - Asia (East \& Southeast Asia) - Hong Kong, Indonesia, South Korea, Malaysia, the Philippines, Singapore, Thailand

SoAsia (South Asia) - Bangladesh, Nepal, India, Sri Lanka, Pakistan

NAME (North Africa \& the Middle East) - Algeria, Egypt, Israel, Morocco, Oman, Syria, Saudi Arabia, Tunisia

Source: World Development Indicators, CD-ROM (1961-1995), United Nations (1998), \& World Bank (1997). 
Table 2: Relative Per Capita Incomes by Region, 1961-1997

(absolute numbers in US\$ of 1990)

\begin{tabular}{|c|c|c|c|c|c|c|}
\hline 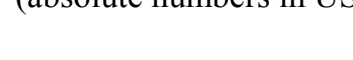 & OECD & $\underline{\text { SSA }}$ & $\underline{\mathrm{LA}}$ & ESEA & $\underline{\text { SoAsia }}$ & NAME \\
\hline PCY 1961-65 & $\overline{9015}$ & $\overline{306}$ & 1391 & 155 & 185 & 1232 \\
\hline \multicolumn{7}{|l|}{ Percentage of OECD: } \\
\hline $1961-65$ & & 3.4 & 15.4 & 1.7 & 2.0 & 13.7 \\
\hline $1971-75$ & & 2.7 & 13.7 & 1.8 & 1.6 & 15.7 \\
\hline $1981-85$ & & 2.2 & 13.6 & 2.4 & 1.6 & 13.6 \\
\hline 1991-95 & & 1.6 & 11.3 & 3.8 & 1.7 & 8.8 \\
\hline $1996-97$ & & 1.5 & 11.2 & 4.6 & 1.8 & 8.5 \\
\hline PCY 1996-97 & 21,540 & 326 & 2,405 & 982 & 395 & 1,826 \\
\hline $\begin{array}{r}\text { Rate of increase of } \\
\text { PCY, } 37 \text { years* }\end{array}$ & 2.7 & 0.2 & 1.7 & 5.7 & 2.3 & 1.2 \\
\hline $\begin{array}{r}\text { Rate required to regain } \\
1961-65 \text { ratio to } \\
\text { OECD in } 37 \text { years }\end{array}$ & & 5.3 & 3.8 & Not app & 3.1 & 4.3 \\
\hline \multicolumn{7}{|l|}{ (Speculation) } \\
\hline $\begin{array}{l}\text { Predictions, } \\
\text { 1997-2006 }\end{array}$ & & & & $4.5^{*}=$ & & 1.1 \\
\hline $\begin{array}{l}\text { (actual 1994-97) } \\
\text { Percentage of OECD, }\end{array}$ & (2.7) & $(0.3)$ & $(2.0)$ & $(4.1)$ & (2.6) & $(1.2)$ \\
\hline $\begin{array}{l}\text { 2006, WB predictions } \\
\text { (2006, actual 1994-97) }\end{array}$ & & $\begin{array}{c}1.4 \\
(1.2)\end{array}$ & $\begin{array}{c}11.6 \\
(10.4)\end{array}$ & $\begin{array}{c}5.6 \\
(5.2)\end{array}$ & $\begin{array}{c}2.2 \\
(1.8)\end{array}$ & $\begin{array}{c}7.2 \\
(7.3)\end{array}$ \\
\hline
\end{tabular}

Note:

A rise in a region's percentage is noted by bold.

PCY - per capita income

*Compound rate, average of 1961-65 to average of 1996-97

**See note to Table 1 .

Table 3: GDP Growth Correlations: OECD and Country Groups, 1961-1997

\begin{tabular}{|c|c|c|c|}
\hline Country group & Elasticity & $\mathrm{R}^{2}$ & F-stat \\
\hline $\mathrm{SSA}^{*}$ & .643 &.$\overline{345}$ & .01 \\
\hline Latin America & .789 & .294 & .01 \\
\hline ESEA & .637 & .252 & .01 \\
\hline South Asia & -.257 & .042 & ns \\
\hline NAME & .884 & .138 & .05 \\
\hline
\end{tabular}

*OECD growth lagged one year. The elasticity using current periods is .518 , with an r-square of .222 . 
Table 4: Net Direct Foreign Investment Flows into Major Industrial Countries, 1980-1996 (billions of current US dollars)

\begin{tabular}{|c|c|c|c|c|c|c|}
\hline & $\underline{\mathrm{USA}}$ & $\underline{\mathrm{UK}}$ & Germany & Japan & Other & Total \\
\hline 1980 & 9.5 & $\overline{-2.5}$ & -2.7 & -2.1 & -2.2 & 0.0 \\
\hline 1981 & 26.2 & -5.3 & -2.7 & -4.7 & -9.1 & 4.4 \\
\hline 1982 & 19.9 & -0.8 & -1.8 & -4.1 & -0.2 & 13.0 \\
\hline 1983 & 18.6 & -1.5 & -1.4 & -3.2 & -1.4 & 11.1 \\
\hline 1984 & 28.3 & -5.2 & -2.5 & -6.0 & -4.1 & 10.5 \\
\hline 1985 & 21.3 & -4.3 & -3.3 & -5.8 & -10.5 & -2.6 \\
\hline 1986 & 26.4 & -3.7 & -7.5 & -14.3 & -9.7 & -8.8 \\
\hline 1987 & 47.3 & -9.0 & -7.8 & -18.4 & -10.0 & 2.1 \\
\hline 1988 & 52.1 & -5.3 & -10.1 & -34.7 & -6.9 & -4.9 \\
\hline 1989 & 51.5 & 3.7 & -7.4 & -45.2 & -15.9 & -13.3 \\
\hline 1990 & 53.0 & 24.5 & -17.1 & -46.3 & -15.8 & -1.7 \\
\hline 1991 & 27.1 & 9.7 & -17.5 & -30.2 & -12.9 & -23.8 \\
\hline 1992 & 4.6 & 5.5 & -16.1 & -14.6 & -0.8 & -21.4 \\
\hline 1993 & 5.0 & -1.4 & -12.6 & -13.7 & 0.1 & -22.6 \\
\hline 1994 & 24.2 & -3.3 & -9.7 & -17.2 & -13.5 & -19.5 \\
\hline 1995 & 5.9 & -5.8 & -23.9 & -22.6 & 17.8 & -28.6 \\
\hline 1996 & 35.4 & 6.7 & -27.1 & -21.7 & -4.0 & -10.7 \\
\hline \multicolumn{7}{|c|}{ unal average } \\
\hline-85 & 20.6 & -3.3 & -2.4 & -4.3 & -4.6 & 6.1 \\
\hline $6-90$ & 46.1 & 2.0 & -10.0 & -31.8 & -11.7 & -5.3 \\
\hline $1-96$ & 17.0 & 1.9 & -17.8 & -20.0 & -2.2 & -21.1 \\
\hline
\end{tabular}

Source: United Nations $(1986,1991,1998)$ 
Figure 1:

Standard Deviation of Growth Rates (natural log)

by Region, 1961-1997 (primary uneven development)

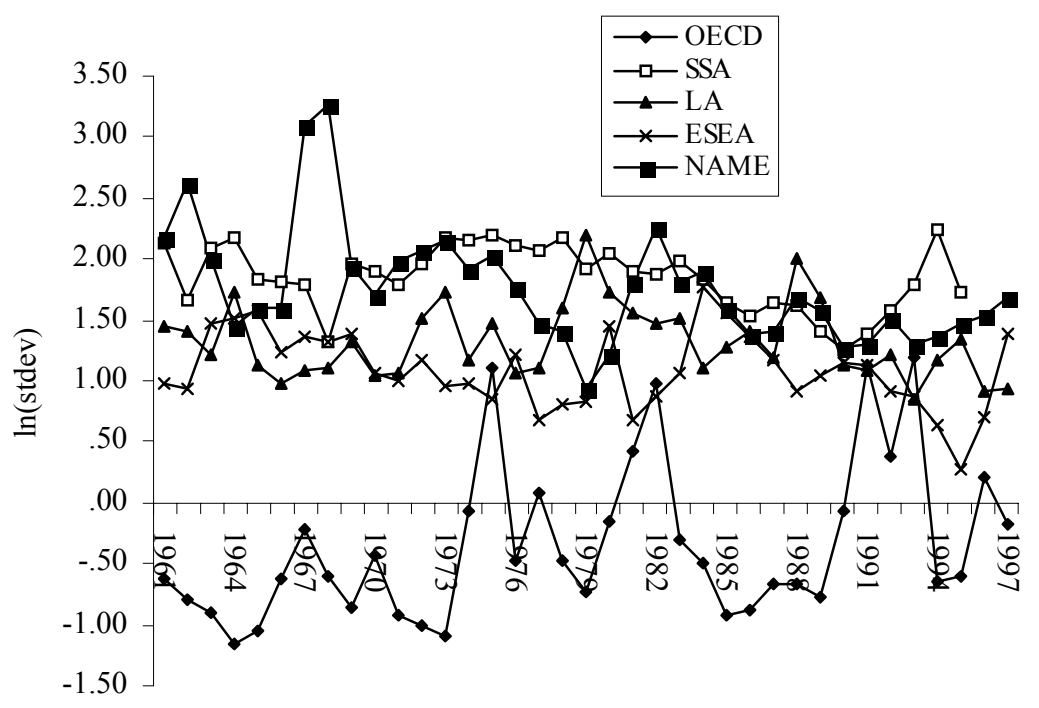

years 
Figure 2:

Differences in Per Capita Growth, the Sub-Sahara, Latin America \& NAME, and the OECD Countries, 1961-1997

(five-year moving average)

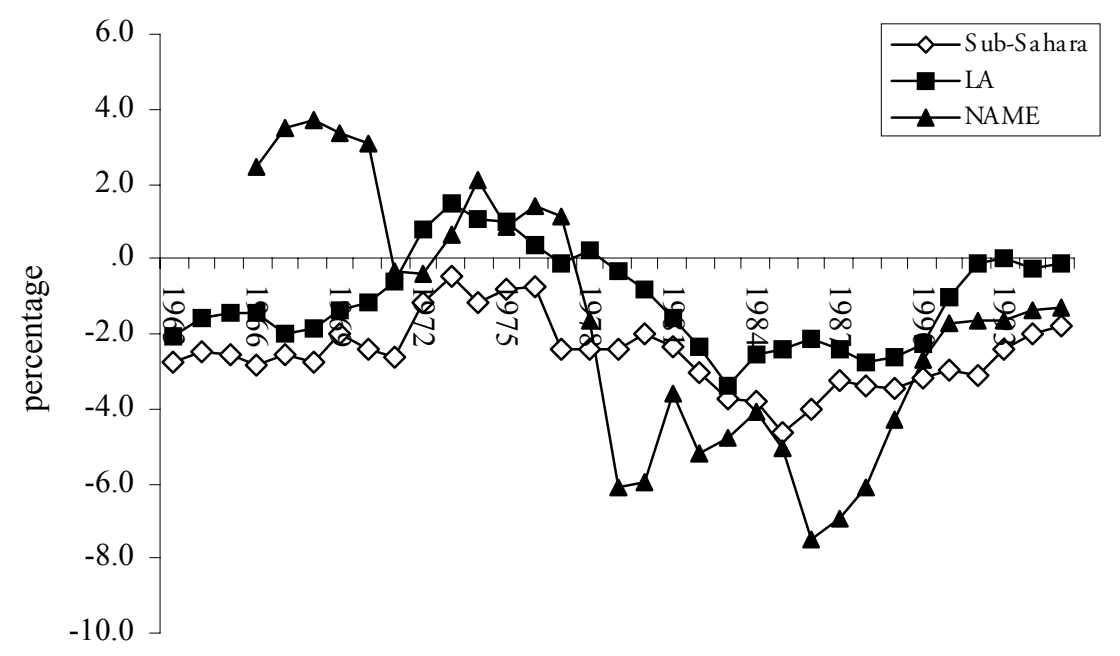

years 
Figure 3:

Differences in Per Capita Growth, ESEA and South Asia, and OECD Countries, 1961-1997

(five-year moving average)

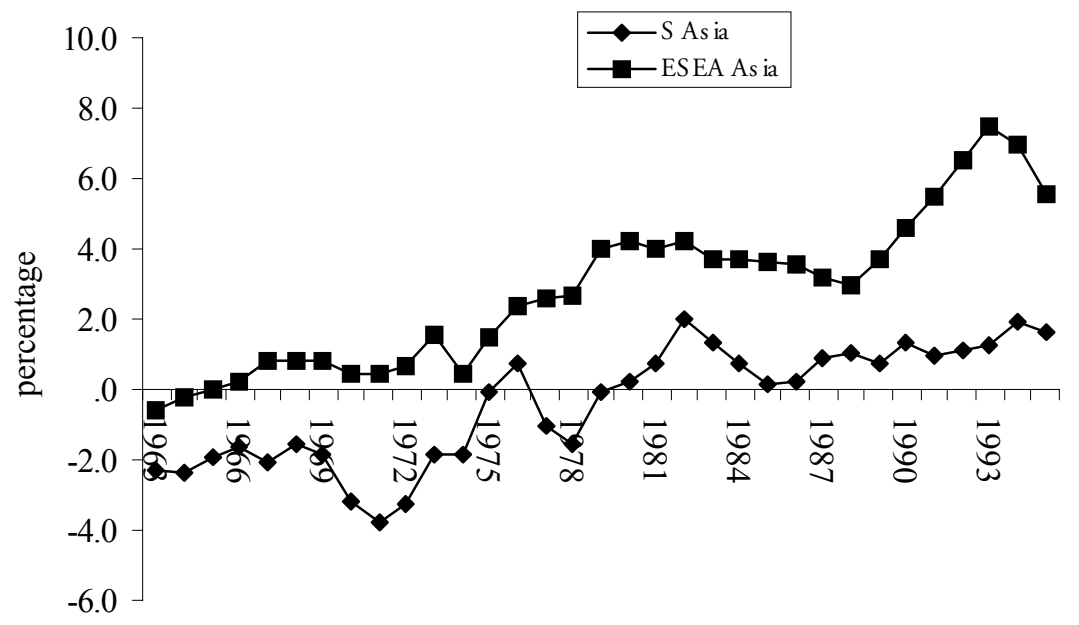

Years 
Figure 4:

Foreign Direct Investment as a Percentage of Gross Domestic Investment, by Region and China, 1970-1995

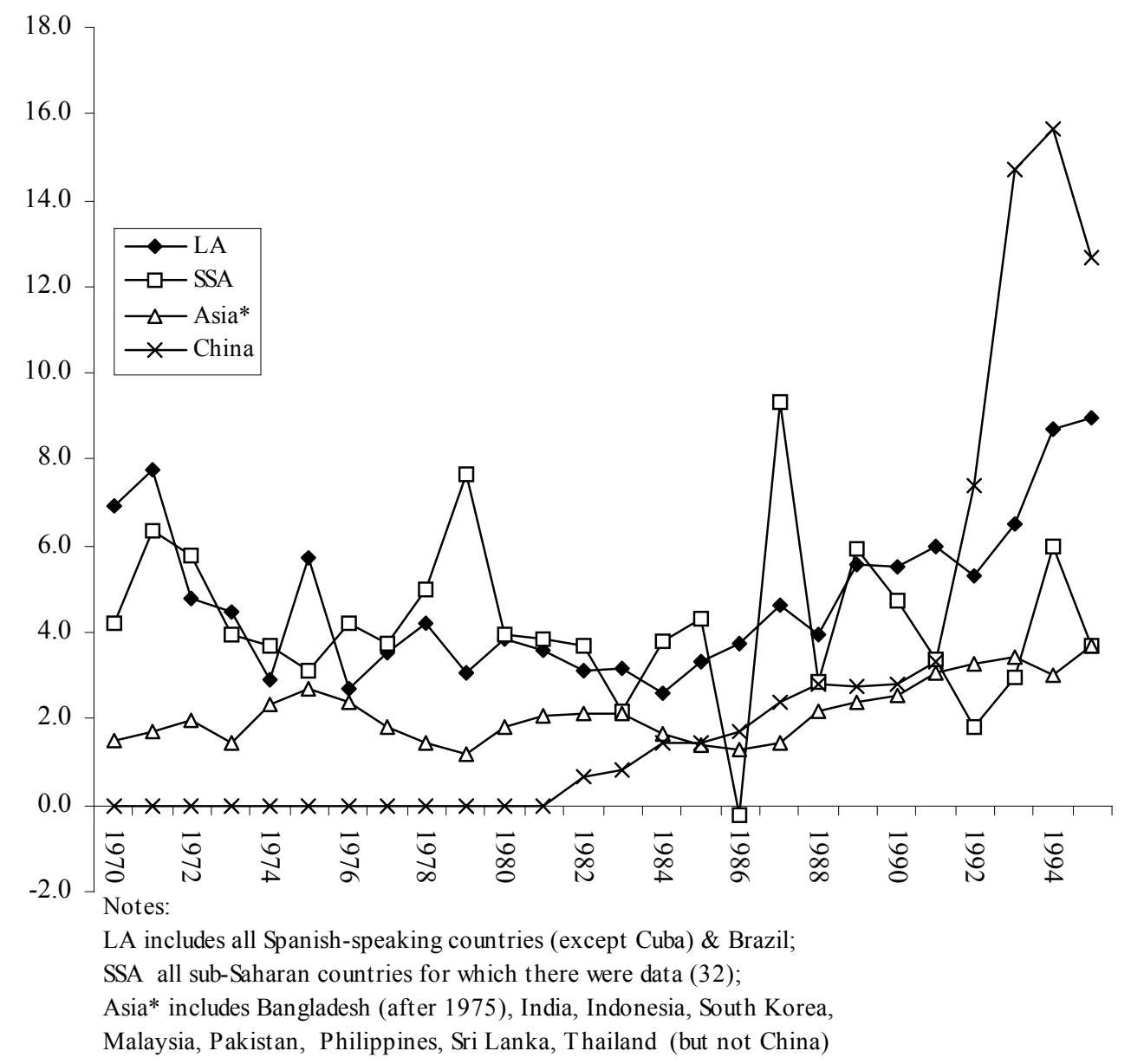


References:

Amin, Samir

1976 Unequal Development (New York: Monthly Review Press)

Dore, Elizabeth, and John Weeks,

1978 'International Exchange and the Causes of Backwardness,' Latin American Perspectives VI (Spring)

Emmanuel, A.

1972 Unequal Exchange: A study in the imperialism of trade (London: New Left Books)

Gerschenkron, Alexander

1962 Economic Backwardness in Historical Perspective (Cambridge: Harvard University Press)

Griffin, Keith

1989 Alternative Strategies for Economic Development (London: Macmillan)

Jones, Charles I.

1997 'On the Evolution of the world Income Distribution,' Journal of Economic Perspectives 11, 3 (Summer), pp. 19-36

Marglin, Stephen, and Juliet Schor

1988 The Golden Age of Capitalism (Oxford: Clarenden)

Pritchett, Lant

1997 'Divergence Big Time,' The Journal of Economic Perspectives 11, 3 (Summer)

United Nations

1986 World Economic and Social Survey (New York: United Nations Secretariat)

1991 World Economic and Social Survey (New York: United Nations

Secretariat)

1997 World Economic and Social Survey (New York: United Nations Secretariat)

United Nations Conference on Trade and Development

Warren, Bill

1997 Trade and Development Report 1997 (Geneva: UNCTAD)

1973 'Imperialism and Capitalist Industrialisation,' New Left Review 81 (September-October)

Weeks, John

1981 Capital and Exploitation (Princeton: Princeton University Press)

1982 'The Differences between Materialist Theory and Dependency Theory and Why They Matter,' in Ronald H. Chilcote (ed.), Dependency and Marxism: Toward a Resolution of the Debate (Boulder, Colorado: Westview)

1985 The Limits to Capitalist Development: The Industrializaton of Peru, 1950-1980 (Boulder, Colorado: Westview)

1989 A Critique of Neoclassical Macroeconomics (London: Macmillan)

1994 'Fallacies of Competition: Myths and Maladjustment in the "Third World",' An Inaugural Lecture, Delivered on 13 October 1993 (London: SOAS)

World Bank

1997 Global Prospects and the Developing Countries 1997 (Washington: World Bank)

1998 World Development Indicators 1998 (Washington: CD-ROM) 